Gramme's patent, made in Paris, and is a double light machine, that is, it has two sets of brushes, and is wound with wire of such a size as to give a current of sufficient intensity for my purposes. It is nominally a 350 candlelirht machine, but the current varies in proportion to the rate of rotation, and I have also modified it by changing the interior connections. The machine can produce as a maximum a light equal to 500 standard candles, or by slowing the rotation of the bobbin the current may be made as feeble as that of the weakest battery. In practical ase it is sometimes doing the work of more than fifty large Grove nitric acid cells, and sometimes the work of a single Smee.

The Gramme machine could not be used to work an induction coil when it first reached me, because when the whole current was sent through the Foucault interruptor of the Ruhmkorff coil, making $\mathrm{r}, \mathrm{Oco}$ breaks per minute, the electro-magnets of the Gramme did not become sufficiently magnetised to give an appreciable current. But by dividing the current so that one pair of the metallic brushes, which collect from the revolving bobbin, supplied the electro-magnets, the other pair could be used for cxterior work, no matter whether interrupted or constant. The current obtained in this way from one pair of brushes when the Gramme bobbin is making I,200 revolutions per minute is equal to 100 candles, and is greater in quantity and intensity than one would like to send through a valuable induction coil. I usually run the bobbin at 622 revolutions per minute, and this rate will readily give $\mathrm{I}, 000$ ro-inch sparlss per minute with the I8inch coil. Of course a Pliicker's tube lights up very vividly and generally; in order to get the maximum effect I arrange the current so that the aluminium terminals are on the point of melting. The glass, particularly in the capillary part, often gets so hot as to char paper. The general appearance of the machine is shown in Fig. $I$.

As long as the Gramme bobbin is driven at a steady rate the current seems to be perfectly constant, but variations of speed make marked differences in the current, and this is especially to be avoided when one is so near the limit of endurance of Plücker's tubes. A reliable and constant motor is therefore of prime importance for these purposes. A difference of one per cent. in the specd in the engine sometimes cannot be tolerated, and yet at another time one must have the power of increasing and diminishing the rate through wide limits. The only motor, among many I have examined and tried, that is perfectly satisfactory, is Brayton's Petroleum Ready Motor.

This remarkable and admirable engine acts like an instrument of precision. It can be started with a match, and comes to its regular speed in less than a minute; it preserves its rate entirely unchanged for hours together. Moreover, it is economical, cleanly, and not more noisy than a steam engine. The one of two-horse power I have, ran for six months, day and night, supplying water ard air to the aquaria in the Centennial Exhibition at Philadelphia. At any time on going into the laboratcry it can be started in a few seconds, even though it has not been running for days.

Henry Draper's Observatory, Hastings-on-Hudson, New York

\section{THE NATURAL HISTORY OF THE FENISSEI}

$A N$ account of the Swedish Overland Expedition $A$ to the Jenissei in the summer of 1876 , the cost of which was defrayed by Mr. Oscar Dickson of Gothenburg, has appeared in the Göteborgs Handels Tidning. The expedition was under the leadership of Dr. Hjalmar Théel of Upsala, who was accompanied by Botany-Docent W. Arnell, Philosophy-Candidate F. Trybom, Zoologist, and Rector M. Brenner, Botanist, from
Finland. Docent Sahlberg, Entomologist, from Helsingfors, also went with the expedition to the Jenissei with the intention of prosecuting independent researches there. The party travelled by Nischni-Novgorod, Perm, Tjumen, Tomsk, and Krasnojarsk on the Jenissei, arriving at the last place on June 8.

We regret that our space permits of our giving only the following account of the natural history of the Jenissei by Dr. Théel :-

The Jenissei has a length of about 1,660 English miles below Krasnojarsk. The banks are sometimes pretty high and bold, sometimes low, alternating in this respect with each other, so that, when the left is high, the right is the opposite. Where the bank is low and exposed to inundations, willows thrive beyond everything. The high banks are clothed with Pinzis obozata and cembra, and larch. At Jeniseisk the river is about $1 \frac{1}{2}$ versts broad, gradually widening northward, till at Kurejka it is five versts broad. Between Tolstonos and Goltschika the river widens and assumes the appearance of a lake more than sixty versts wide. Here the tides are quite observable. At Dudinskoj a depth reaching twelve fathoms was found.

The Russian population of the Jenissei Valley is very sparse and uncivilised, and inferior, as far as the fine arts are concerned, to some of the Asiatic races. Cattle rearing is in its infancy, though there are perhaps few regions more suited for it than the valley of the Jenissei. Cows are met with as far as Dudinskoj, but their proper management did not appear to be understood. At villages on the upper Jenissei, with as many as forty or fifty cows, a glass of milk could scarcely be obtained. The making of cheese is completely unknown, the making of butter nearly so. There are horses as far north as Dudinskoj, sheep only to Vorogova, and no goats north of Jeniseisk. Cultivation is at a still lower standpoint, rye not being at present grown below Antsiferova, sixtyseven versts north of Jeniseisk, and oats to Zotina, $60^{\circ} 55^{\prime}$ N. lat. Potatoes are grown to Turuchausk, but are there very small. For some years Skoptzi settled on the Chantajka river, $68^{\circ} 20^{\prime} \mathrm{N}$. lat., have successfully grown potatoes.

Fish forms the principal food of the people, and during summer nearly every one is a fisher. Fishing is carried on with various kinds of nets, with lines and hooks, and even with leister and torch. There are found in the Jenissei pike, ruffe, perch, burbot, Cyprinus curassius, tench, Thymallus vulgaris, several species of the family Leuciscus, among them one which strongly resembles our common roach, a. kind of Petromyzon, Gasterosteus pungitius, a kind of bullhead (Cottus), \&c. All these are of inferior importance for domestic use, and mostly serve as food for dogs. The more valuable are the sturgeon, salmon, and coregonus. There are two varieties of sturgeon, the commoin sturgeon or "Ossetrina," Accipiter sturio, and the sterlet, Ac. mithenus. The Ossetrina is caught along the whole Jenissei, and sometimes reaches a. weight of $225 \mathrm{lbs}$. The sterlet is not found north of Dudinskoj, and commonly weighs 3 or 4 lbs., but sometimes reaches 18 lbs. There is another called the prickly sturgeon, "Kosterska," believed to be the young of the Ossetrinc. There are many varieties and transition forms of sturgeon, rendering their proper classification difficult. The salmon is most numerous in the upper course of the river at Minousinsk, where a profitable fishery is carried on. "Two types are distinguished, "Tajmen" and "Kunschja." The former is caught in greatest numbers in the upper course of the river, and weighs 40 to 60 lbs. ; the latter is found in lakes on the tundra, and very seldom in the Jenissei below Dudinskoj. At the Nichandrovska Islands a salmon, probably a Tajmen, was caught, which was nearly five feet long and weighed between 80 and roo lbs. Of the Coregonus the following species were found in the Jenissei :-Njelma (C. leucichthys), Tschir 
(C. nasutus), Muksun (C. muksun), Peljedka (C. peiet), Omul (C. omul), Common Siklöja or Seldj (C. albulla?).

The common Coregonus is said to be found in the Jenissei the whole year round. The Tschir, Njelma, and Muksun are seen almost simultaneously in early spring, the Tschir first beginning to ascend, and then the other two almost simultaneously, or the Njelma rather earlier. Finally masses of the Siklöja, and last of the Omul, make their appearance. These seldom go above the rapids between Podkamennoje Tunguska, and Asinova. There is no accurate information about the Pelet, but it does not appear to go far from the mouth of the river.

The bird world was sparingly represented on the Jenissei. In the south the Passeres were most numerous. In the neighbourhood of the limit of trees on the tundra and at the Briochovska and Nichandrovska Islands the swimming birds and waders first became more numerous. Colymbus septentrionalis, Harelda glacialis, Oidemia fusca and nigra, Fuligula marila, Anas ponelope and acuta, and Cyonus bezvickii occurred here in great numbers, but with a few others were the only species of the order Natatores that could be found in those northern regions. A number of birds, for instance geese, Anser segetum and albifrons, and swans, occur first at the period of migration in antumn, when the uncommon red-necked goose, Anser ruficollis, is also met with not unfrequently. Altogether I 40 to I 50 species, of which only fifteen to twenty were extra-Scandinavian, have been observed during the summer, among them about twenty-five Natatores and twenty Raptores. It is singular that, for instance, at Tolstonos, $69^{\circ} 55^{\prime} \mathrm{N}$. lat., accordingly beyond the limit of trees, many small birds belonging to the order Passeres occur. Schmidt there found ten species, to which number we are able to add four more, viz., Fringilla linaria, Emberiza pusilla, Saxicola ananthe, and Phyllopneuste trochilus. A number of birds in Siberia are found drawing more and more to the west. It is stated, for instance, that the species, Aluuda alpestris, Emberiza rustica, and pusilla, \&c., which formerly could only be met with in Siberia and Eastern Russia, are now found in Finland and Western Russia, and indeed even within Scandinavia. In the time of Pallas the Ural formed the western limit of the Emberiza aureola, which is now common in the whole north of Russia. It is therefore not impossible that part of the birds at present peculiar to North Russia and Siberia may in the future belong to the fauna of Sweden. Trybom states that at Krasnojarsk, the insect fauna was abundant and very unlike the Scandinavian. As the party descended the river the insects diminished in number more speedily than could have been expected, those strangest to the Swedes generally disappearing first. Where the wood had been burned lately, and vegetation had not been able to regain its ordinary condition, the insect fauna was also poor. Compared with the phanerogamous plants occurring within the same area the Scandinavian insects taken overhead are immeasurably more numerous than those of the Jenissei River Valley. It is on the tundra that the most which are common to Scandinavia are found. In the collections made the Coleoptera are most numerously represented, then the Hymenoptera, Diptera, Lepidoptera, Neuroptera, and Orthoptera. The number of species collected is believed to exceed 1,000 , among them about fifty kinds of diurnal Lepidoptera. Of these two-thirds are Scandinavian. Of the insects collected about Krasnojarsk only the half are Swedish. The four species (Colias palceno, L., and Boothii, Ross, Pieris napi, L., and Argynnis pales, W. V.) found at the Nikandrovska Islands are all Swedish. The distribution to the north or south was for many species different from that in Scandinavia. Thus Pararga hiera, Hübn., ceased there at least three degrees farther south than in Sweden. Lycena acis, Ochs, was not found farther north than at Nikulina, $60^{\circ} 25^{\prime} \mathrm{N}$. lat. Pieris daplidice, L., was, on the other hand, found as far as Fatianova and
Lycena argiolus, L., at Turucharsk $\left(65^{\circ} 55^{\prime} \mathrm{N}\right.$. lat. $)$, Heteropterus syluius, Knock., which was very common as far as Krasnojarsk, was also found there. Argynnis aphirape, Hübn., is found in Sweden six degrees farther south than it was seen on the Jenissei, but Arg. freja, Thbg., on the contrary, two degrees more to the south in the latter place. Polyommatus helle, W. V., is pretty common on the Jenissei, two degrees farther south than in Sweden.

Arnell states that the moss flora of the Lower Jenissei, like that of the whole of Siberia, generally may be said to be almost completely unknown to science, only eighteen species of mosses being previously known. The number collected during the expedition may, perhaps, as far as may be judged before the material is thoroughly worked out, be reckoned at about 300 , many being foreign to Scandinavia and many even new to science. The most peculiar localities on the Lower Jenissei are the tree stems on the banks, which are periodically overflowed. The stems receive a coating of earth often to a height of many feet above the ground, and form an excellent locality for mosses. Here are found not only some Scandinavian mosses as Leskea polycarpa, Myrinia, Amblystegium riparium, Fontinalis hypnoides, Neckera undulata, Homalia trichomanoides, Pylaisea (in an unending variety of forms), \&c., but also and especially by two non-Scandinavian mosses, namely, the uncommon genuine Timmia negapolitana and an exceedingly pretty Eurhyn. chimm concinnum, formerly referred to Mynrella or a peculiar family of Achrolepis, but undoubtedly belonging to Eurhynchium

The masses of decayed stems found in the forests in incomparably larger numbers than in Scandinavia form another peculiar locality. They are characterised especially by Dicrana fragilifolium and fuscescens, which here exhibit all possible transition forms to each other, and a number of Hepatice, part of them foreign to Sweden. Mountain localities, especially with primitive rocks, are seldom met with on the Jenissei. The mosses peculiar to primitive rocks were found very sparingly. Grimmia and Rhacomitrium were seldom met with. Of these two families Grimmia apocarpa, which is not particular as to what it grows on, is the only species which in some degree is dis. tributed over the region. Only once was a Rhaconitrium found in the whole distance from Krasnojarsk to the limit of trees, about 1,660 miles; first north of the limit of trees the family began to take to some extent the place it has in Sweden. The moss flora of the Lower Jenissei may be said to be specially characterised by its richness in Mnia and Marchantiacea. The following were also richly represented :-Splachnacece (with eight species), Poly. trichum, Bryum (particularly towards the north, in very beautiful forms, partly new), Webera, Dicrimum, Encalypta and Sphagmum, \&c. Some of the greatest Scandinavian rarities were found, as Orthothecium intricatum, Mynrella julacea and apiculata, Hylocominm oakesii, Pogonatum capillare, Oligotrichum larigatum, Cinclidium subrotundum, all avith fruit. Enormous masses, in which two species of Riccia occurred, were found close to the water's edge on the clay banks inundated during summer the whole way from the Nikandrovska Islands to Jeniseisk. In Scandinavia the northernmost representative of this family does not go farther north than about the sixty-second degree of latitude. Extensive collections of fresh-water algæ were also made, but no detailed account of them can yet be given.

Arnell states that somewhat over yoo herbaceous plants were collected during the summer at about sixty different points on the Jenissei ; of these about 200 are foreign to Sweden. Several families and races, as Gymnosperma, Androsace, Pedicularis, and Anemone are richer in species on the Jenissei than in Scandinavia; the following races numerously represented in Sweden are sparingly met with on the Jenissei :-Hieracium, Campanula, Veronica, Tri- 
folium, Geranium, Sedum, \&c. The forests which clothe the banks of the Jenissei consist to a great extent of nonScandinavian trees, namely, of the larch, Pinzes cembra, Abies sibirica, and the Abies obovate, which scarcely differs from Pinus abies, and of Populus nigra. Of the trees common to Scandinavia the most important are the birch (Betula verrucosa and glutinosa), pine, aspen, bird's cherry, and mountain ash. Besides, the Salices play a very important part on the Jenissei, inasmuch as they form extensive woods on the low banks periodically overflowed; these Salices often grow to uncommonly large sizes, and consist in part of non-Scandinavian species, one of which, Salix vitellina, is the most common of all, and spreads over the whole of the region examined by the botanists of the expedition.

The bush vegetation too in Siberia exhibits differences from that of Scandinavia. On the Jenissei Alnaster fruiticosies is important beyond others, because it forms thickets, and especially towards the north increases in mass, going in that direction beyond the limit of trees. Among other bushes foreign to our flora there occur on the Jenissei the Siberian pea tree (Robinia), Spirce confusa, sorbifolia and salicifolia, Sambucus racemosa, Cratagus sanguined, Cassandra calyculato, peculiar types of roses, \&c. Among the bushes common to Scandinavia the most important are the black and red currant, dwarf birch, Lonicera corulea, which is far more widely distributed than in Sweden, juniper, Myrica gale, raspberry, Empetrum nigrum, Vaccinium vitis idac, and myrtillus, \&c. Towards the north the bushy Salices play an important part, as in our northern regions. On the Jenissei there has been found only one species of $A$ lnzks, which is specially interesting as not being either of the Swedish species, but perhaps the genuine Alnuts pubescens. On the other hand there are absent on the Jenissei many of our trees and bushes, as the nobler deciduous trees and fruit trees, and, what may be said to be distinctive of the Jenissei flora, heather, which is so extensively distributed in Sweden, is wanting.

\section{TEMPERATURE AND HUMIDITY OF THE} AIR AT DIFFERENT HEIGHTS

$A$ MEMOIR on the temperature and humidity A of the air at different hours, by Dr. H. E. Hamberg, based on observations made by him during the summer of 1875 , at heights varying from 2 inches to 22 feet above the ground, was published recently in the Transactions of the Royal Society of Sciences at Upsal. The memoir is a valuable one, and is of interest to more than the mere meteorologist, it being evident that the inquiry is so handled as to bring it into close connection with such difficult questions as convection currents in the free atmosphere and the diffusion of vapour through the air.

In clear weather the temperature of the air nearest the surface was lower than that above it, from two to three hours before sunset to at least two to three hours after sunrise. At all the six heights the temperature fell to the minimum at the same hour, viz., about 3 A.M. ; but while it continued from this time to rise steadily at all the heights, the lowest temperatures continued to be observed in the strata nearest the ground till several hours after sunrise. From this remarkable result Dr. Hamberg concludes that the increase of temperature in the lower strata of the air in the early part of the forenoon is not an immediate and direct consequence of the heating of the ground, but is rather to be attributed to the absorption by the air, or more strictly by its aqueous vapour, of the heat received from the sun's rays or reflected from the ground.

Over uneven ground covered with vegetation the temperature near the surface is generally higher over those parts of the field which rise above the general level. Thus even slight elevations of only one or two feet have the air immediately resting on them often $2^{\circ}$ higher or mure, whilst on the other hand, a trench or depression one or two feet below the general level has the air resting on it often $2^{\circ}$, or more, lower than the air over the level portions of the field, a result of considerable practical importance in agriculture and horticulture.

The latent heat set free on the formation of dew appears from the observations clearly to retard the lowering of the temperature, but not to the extent which might have been expected. When, on the deposition of dew, the temperature of the air near the surface has fallen below $32^{\circ}$, as soon as the dew is congealed into hoar-frost the temperature of the lowest stratum of air in contact with the ground instantly rises to $32^{\circ}$; but at the same time the temperature of the air higher up steadily remains lower than $32^{\circ}$.

The absolute humidity of the air on clear nights on which no dew is deposited decreases from the ground upwards, just as happens during the day; but on the other hand, with dew, the humidity is least nearest the ground, and increases with the height, and this influence of dew, in diminishing the humidity, extends lupwards to at least twenty-two feet, the height to which the observations were carried. Since his observations clearly show that the absolute humidity begins in the evening to diminish near the ground before any dew is observed to be deposited, and also diminishes at all heights on those nights during which no dew whatever is formed, Dr. Hamberg is of opinion that the diminution of the humidity of the air during night is to be sought for in other physical causes than the deposition of dew.

Several of the points discussed will doubtless be made subjects of further investigation by others. In all cases it is most desirable, indeed absolutely necessary, to a critical valuation of the observations, that the authors give woodcuts and descriptions of the exact position and mode of protection adopted in the case of each thermometer employed in the observations. For such refined inquiries the method of observation must necessarily be a refined one ; in other words, such as will certainly secure the necessary comparability among all the instruments.

THE CHRONOMETERS OF SWITZERLAND

$W^{E}$ find in a recent number of the Bulletin of the Society of Natural Sciences at Neuchâtel an interesting report of the Neuchâtel Observatory on the annual competition of chronometers for prizes awarded yearly by the Observatory. The report gives some idea of the degree of perfection reached in Switzerland in the construction of chronometers. The 231 chronometers (four box and 227 pocket chronometers) admitted to the competition out of 270 sent in were submitted to a severe test, including changes of temperature and of position during periods of from two weeks to two months, and the results of the trial appear as follows. The average diurnal variations in the rates of the box-chronometers proved $0^{\circ} 32$ sec. (against $0^{\circ} 20$ in 1874 ), and of the pocleet ones 0.46 sec. (against 0.53 in 1874), and there was but two per cent. of these last, the average diurnal variation of which reached I sec. The various systems of escapements appeared, as was observed in former years, to have but little if any influence on the degree of precision of watches, provided they remain constantly in the same position, vertical or horizontal. The compensation for changes of temperature proved to bealtogether satisfactory, the average variation of 167 chronometers submitted to variations of temperature from I 5 to 25 Cent. degrees being but $0^{\prime} I 3$ sec. for each Centigrade degree. It must, however, be noticed that only 5 I per cent. of them showed variations below one-tenth of a second for each degree, and that to per cent. showed variations above $0^{\circ} 3 \mathrm{sec}$. Finally, the differences between the rates during the first and the last weeks were: for box-chronometers, 2 I I sec. 